\title{
ІНШОМОВНА НЕОЛЕКСИКА В ЕКОНОМІЧНОМУ ДИСКУРСІ
}

\author{
Архипенко Л. М., Мельник П. В.
}

\section{ВСТУП}

Активізація вживання іншомовних слів в українському мовленні кінця XX - початку XXI ст. - один із найбільш живих і соціально значущих мовних процесів. Варто говорити не лише про активізацію використання цих лексем, а й про нові запозичення, оскільки поряд із розширенням сфер використання спеціальної іншомовної термінології в галузях економіки, фінансів, комерційної діяльності тощо спостерігається поява запозичень-неологізмів. I ці процеси, звичайно ж, вимагають аналізу й узагальнення.

Інтенсивність i значущість процесу запозичення іншомовної лексики в українську мову привернули значну увагу багатьох науковців. О. Стишов ${ }^{1}$, В. Симонок ${ }^{2}$, М. Навальна ${ }^{3}$ розглядають запозичення як ефективний спосіб поповнення лексичного складу мови; С. Федорець ${ }^{4}$ досліджує англійські запозичення в мові сучасної української реклами; запозичення в українській науково-технічній термінології досліджує О. Лисенко . Окреме місце посідають дослідження іншомовних запозичень в економічних терміносистемах. Англіцизми в українській мікроекономічній термінології розглядає А. Олійник ${ }^{6}$ О. Чуєшкова ${ }^{7}$ досліджує аналітичну номінацію в економічній терміносистемі; Д. Романчук і О. Ковальчук ${ }^{8}$ аналізуюють процес формування іншомовних запозичень в українській економічній

\footnotetext{
${ }^{1}$ Стишов О. Українська лексика кінця ХХ століття (на матеріалі засобів масової інформації). Київ : КНЛУ, 2003. 388 с.

${ }^{2}$ Сімонок В. Мовна картина світу. Взаємодія мов. Харків : Основа, 1998. 171 с.

${ }^{3}$ Навальна М. Динаміка лексикону української періодики початку XXI ст. Київ : Інститут української мови ; Видавничий дім Дмитра Бураго, 2011. 328 с.

${ }^{4}$ Федорець С. Англійські запозичення в мові сучасної української реклами : автореф. дис. ... канд. філол. наук. Харків, 2005. 20 с.

Освоєння німецькомовних запозичень в українській науково-технічній термінології : дис. ... канд. філол. наук. Харків, 1999. 170 с.

6 Олійник А. Роль запозичень-англіцизмів у розвитку сучасної української мікроекономічної термінології : автореф. дис. ... канд. філолог. наук. Київ, 2002. 20 с.

${ }_{7}$ Чуєшкова О. Аналітичні номінації в економічній терміносистемі (структурнотипологічний аспект) : дис. ... канд. філол. наук. Харків, 2002. 189 с.

${ }^{8}$ Ковальчук О., Романчук Д. Розвиток іншомовних запозичень в українській економічній лексиці. Наукові записки Національного університету «Острозька академія». Серія «Філологія». 2013. Вип. 37. С. 149-151.
} 
лексиці, С. Стецюк ${ }^{9}$ Л. Архипенко ${ }^{10}$ у своїх розвідках звертають увагу на англіцизми у фінансово-економічній термінології. Однак інтенсивне поповнення лексикону української мови новими запозиченнями в умовах глобалізації вимагає постійного дослідження.

Визначальною рисою сучасної мовної ситуації $\epsilon$ надмірне запозичення англіцизмів. У кінці XX ст. характерною стає так звана українська америкоманія. Її особливістю $\epsilon$ настанова на західний спосіб життя, на деяку асиміляцію 3 американською культурою й цивілізацією, унаслідок чого американізми стали приходити в українську мову вже не як екзотизми. I звичайно ж, причина тут у нових суспільних уподобаннях - «у свідомій настанові на підкреслено вільне мовлення, на мову, звільнену від спущених згори заборон» ${ }^{11}$. За В. Костомаровим зазначимо, що сучасні мовні уподобання (перевага американізмів) пояснюють заміни французьких слів жаргон, екран, макіяж англіцизмами сленг, дисплей, майкап, топ-модель. Також зауважмо: замість українських слів німецького походження бутерброд $i$ шлягер тепер часто іноді говорять сендвіч або навіть гамбургер / чизбургер і хіm. Якщо українці у XIX ст. імпортували Savoi Faire, то зараз вивозять know-how (або ноу-хау) з Америки. Початок 90-х XX ст. років характеризується також і поповнюванням українського лексикону економічними англіцизмами. В українську мову потрапляє велика кількість економічних, фінансових, комерційних, торгових термінів 3 англійської мови: андеррайтинг, лізинг, бартер, дилер, дистриб'ютор, мерчандайзер, промоушен, холдинг тощо. Галуззю, на частку якої припадає найбільша кількість англіцизмів, звичайно ж, стає економіка й пов'язана $з$ нею економічна комунікація. Це зумовлено розвитком міжнародних економічних зв'язків, глобалізацією економіки, запозиченням західних передових технологій і підвищенням ролі англійської мови як засобу міжнаціонального спілкування. Здобуття Україною незалежності, міжкультурна комунікація стали причиною запозичення численних економічних термінів й орієнтиром на західну економіку та використання інтернаціональної термінології. 3 огляду на суспільну актуальність явища, позначувані цими термінами, й самі терміни опиняються поза межами професійного мовлення й широко

9 Стецюк С. Англомовні запозичення в українській фінансово-економічній термінології. Проблеми украӥнської термінологї : збірник наукових праць учасників XII Міжнародної наукової конференції «Проблеми української термінології СловоСвіт 2012», Львів, 27-29 вересня 2012 р. Львів : Видавництво Львівської політехніки, 2012. С. 52-54.

${ }^{10}$ Архипенко Л. Особливості адаптації запозичень із німецької мови в систему української економічної термінології. Одеський лінгвістичний вісник. Спецвипуск. 2017. C. 26-29.

${ }^{11}$ Костомаров В. Языковой вкус эпохи. Москва, 1994. 218 с. 
використовуються в повсякденному спілкуванні. Саме тому все більшого значення набуває вивчення особливостей інтеграції англіцизмів в україномовну економічну комунікацію.

Мета роботи - подати характеристику своєрідності процесу інтеграції новітніх англіцизмів в українську термінологію економічної галузі; на матеріалі засобів масової інформації здійснити аналіз англіцизмів і дослідити функції, зреалізовані ними в українському економічному дискурсі.

\section{1. Своєрідність процесу інтеграції запозичень-неологізмів в українську економічну термінологію}

Процеси мовного запозичення складні за своєю природою й особливо цікаві в контексті динаміки сучасних міжнародних відносин і мовних контактів. Питання, пов'язані 3 особливостями міжмовної взаємодії, досліджуються вже понад століття, і сьогодні запозичення як поняття існує у варіативних інтерпретаціях багатьох лінгвістів. Науковцві намагалися дати визначення терміна «запозичення» з різних позицій. Аналізуючи думки мовознавців про процес запозичення, спостерігаємо неоднозначність у тлумаченні цього поняття. По-перше, процес запозичення прирівнюється тільки до «лексичного» запозичення (О. Ахманова ${ }^{12}$, Д. Розенталь ${ }^{13}$, Ю. Сорокін ${ }^{14}$ та інші). Такий погляд був характерним і для визначення поняття запозичення в кінці XIX - на початку XX ст. Не знайшло відображення в цих визначеннях явище асиміляції іншомовного слова в мові-одержувачі (за винятком визначення Ю. Сорокіна). Нарешті, запозичення повністю заперечується як процес М. Майоровим ${ }^{15}$. Нам важко погодитись із такою позицією. Доцільним, на наш погляд, $є$ визначення терміна «запозичення», подане в «Енциклопедії української мови»: «Запозичення - звук, морфема, слово або його окреслене значення, фразеологізм, синтаксична конструкція, перенесені з однієї мови в іншу, а також сам процес подібного перенесення» ${ }^{16}$. На нашу думку, це визначення може бути доповнене таким чином: «причому елементи

12 Ахманова О. Словарь лингвистических терминов. Москва : Советская энциклопедия, $1966.606 \mathrm{c.}$

${ }^{13}$ Розенталь Д., Теленкова М. Словарь-справочник лингвистических терминов. Москва : Наука, 1976. 543 с.

14 Сорокин Ю. Развитие словарного состава русского литературного языка в 30-90-е годы XIX века.. Москва ; Ленинград : Наука, 1965. 159 с.

15 Майоров М. К вопросу о сущности лексического заимствования. Ученые записки 1-го Московского государственного института иностранных языков им. М. Тореза, 1967. Т. 37. С. 196-235.

16 Українська мова : енциклопедія. Київ : Вид-во «Українська енциклопедія» ім. М.П. Бажана, 2004. 820 с. 
чужої мови, асимілюючись мовою-одержувачем, у свою чергу, певним чином, впливають на систему мови, яка запозичує».

Отже, запозичення - це й процес освоєння елемента чужої мови, i сам цей елемент. Під «елементами» чужої мови розуміємо одиниці різних рівнів мовної системи: фонетики, морфології, лексики, синтаксису. Унаслідок цього варто обмежувати термін «запозичення» на кожному рівні: фонетичне запозичення, семантичне запозичення, лексичне запозичення, морфологічне запозичення, синтаксичне запозичення.

Сьогодні немає загальноприйнятого тлумачення терміна «запозичене слово». Так, в О. Ахманової «запозичене слово» - це «слово, що 3'явилося в певній мові як результат запозичення» ${ }^{17}$. Е. Хауген уважає, що про запозичене слово говорять тільки в тих випадках, коли 3 іноземної мови запозичуються як значення, так i звукова оболонка слова ${ }^{18}$. Запозичені слова він поділяє на «власне запозичені слова» (pure loanwords) i «гібридні запозичення» (loan blends) залежно від того, переносяться запозичені слова повністю чи частково.

Кожне запозичене слово створюється з іншомовного матеріалу, як зауважує Л. Єфремов, а матеріалом для запозичення може бути тільки звучання слова й матеріальне значення, властиве слову в тих чи інших випадках його усталеного вживання ${ }^{19}$.

«Енциклопедія української мови» дає таке визначення терміна «запозичене слово»: «Запозичені слова - іншомовні слова, цілком засвоєні мовою, що їх запозичила. Запозичені слова не сприймаються мовою як чужорідний елемент і не потребують пояснень щодо форми i значення. На відміну від іншомовних слів, які розглядаються у спеціальних словниках, запозичені слова подаються в загальних словниках разом 3 питомою лексикою» ${ }^{20}$.

Ми вважаємо найбільш повним визначення поняття «запозичене слово» як слова, освоєного в мові-рецепторі, включеного до іiі системи («Енциклопедія української мови» ${ }^{21}$, Л. Крисін ${ }^{22}$ ).

17 Ахманова О. Словарь лингвистических терминов. Москва : Советская энциклопедия, 1966. С. 151.

18 Хауген Э. Лингвистика и языковое планирование. Новое в лингвистике. Вып. 6. Москва : Погресс, 1975. С. 352.

19 Ефремов Л. Сущность лексического заимствования и основные признаки освоения заимствованных слов : автореф. дис. ... канд. филол. наук. Алма-Ата : Казахск. ун-т, 1959. С. 7-8.

20 Українська мова : енциклопедія. Київ : Вид-во «Українська енциклопедія» ім. М.П. Бажана, 2004. С. 179.

${ }^{21}$ Там само. 
Характерною рисою іншомовних лексем $є$ особлива структура, підпорядкована словотвірним моделям, наявним в англійській мові, і це викликає певні труднощі під час їх адаптації на українському грунті. Процес запозичування в українську мову й формування певного англомовного контенту має назву «англізація» і $\epsilon$ найбільш знаковим i актуальним явищем у розвитку сучасного соціуму. На думку В. Пілецького, «англіцизм, як і будь-яке інше запозичене слово, доречний, якщо він позначає поняття, що 3 різних причин ще не назване засобами української мови або в ній відсутній рівновартісний відповідник, за наявності ж у мові питомих або запозичених термінів, що прижилися в мові, англіцизми сприяють «вимиванню» власне мовних термінів» ${ }^{23}$.

Розглянемо причини запозичення іншомовних слів, зокрема й економічних термінів з англійської мови:

1) потреба в найменуванні нових понять і явищ: інфляція, бізнес, приватизачія;

2) спеціалізація понять: маркетинг (англ. marketing - «ринок»), менеджмент, aydum (англ. audit - «ревізія»), лізинг (англ. leasing «орендна з подальшим викупом»);

3) сформовані системи інтернаціональних термінів на основі англійської мови: лендінг (англ. landing - «плата за розвантаження товару»), ролл-овер (англ. rollover - «відновлення терміну кредиту»);

4) мода на іншомовне слово, престижність запозичення. Наприклад, opic (англ. office - «контора»), аудитор (англ. auditor «ревізор»), франчайзинг (англ. franchising - вид відносин між ринковими суб'єктами).

I. Огієнко основну причину запозичення нових слів убачав у нерівномірності культурного розвитку народів-сусідів; «чим культурніше і оригінальніше народ, тим сильніше він впливає на сусідів» ${ }^{24}$.

Процес англізації галузі економіки в українській мові протягом декількох останніх десятиліть має стійку тенденцію до прискорення. Як результат розвитку взаємозв'язків із західноєвропейськими країнами у сфері економіки в лексику української мови проникають численні фінансові й комерційні терміни: дилер (англ. dealer - «торговець»,

${ }^{22}$ Крысин Л. К определению терминов «заимствование» и «заимствованное слово». Развитие лексики современного русского языка. Москва : Наука, 1965. С. 35.

23 Пілецький В. Мовна самобутність терміна. Украӥнська термінологія $i$ сучасність : збірник наукових праць. 2009. Вип. VIII. С. 52.

${ }^{24}$ Огиенко И. Иноземные элементы в русском языке: История проникновения заимствованных слов в русский язык. Киев : Тип. Бондаренко и Гнездовского, 1915. $136 \mathrm{c}$. 
«агент»), маркет (англ. market - «ринок»), офиор, офшорні кошти (англ. offshore - «вільний», «що знаходиться на відстані від берега, у відкритому морі»), демпінг (англ. dumping - «зниження», «зменшення»; «гальмування розвитку»). Про те, що слова міцно закріпилися на українському грунті, свідчить їх метафоризація й підпорядкування українській граматиці. Іншомовне слово не тільки граматично вживається в лексичне оточення, а й пристосовується до українського слововживання.

Варто зауважити, що ці слова були запозичені українською мовою саме в зазначеній формі, а похідні від них слова орендний, орендодавець, банківський, дилерський, дилерство, іпотечний є українськими, адже утворені за допомогою питомих українських словотвірних засобів. Зважаючи на суспільну актуальність позначуваних цими термінами предметів і явищ, вони виходять за межі професійної сфери. Як зазначає Г. Онуфрієнко, «номінуючи численні витвори національного інтелекту в науково-технічному просторі, гібридні терміни переконливо й наочно відбивають прогресивну тенденцію до інтернаціоналізації, але в умовах збереження національних особливостей термінологічного фонду» ${ }^{25}$.

Існують сфери, де використовуються спеціальні терміни. Це, розраховані на фахівців тексти наукового стилю, які не потребують будь-яких коментарів i роз'яснень. Наприклад: демередж (англ. demurrage - попередньо узгоджена додаткова плата власнику судна $з$ боку власника вантажу (фрахтувальника). Ставка демереджу зазвичай передбачається в чартері); детеншен (англ. detention - час простою судна після контрсталії. На відміну від демереджу, збитки за простій судна в цьому випадку оплачуються не частково, а в повному обсязі); ф'ючерс (англ. futures - вид строкових угод на товарній або фондовій біржі: купівля-продаж умов майбутніх контрактів із фіксацією іх терміну. Ф'ючерсні контракти закінчуються реальною поставкою вкрай рідко).

Словники фінансово-економічної лексики ${ }^{26}$ містять значну кількість матеріалу 3 різних джерел (засоби масової інформації, художня й наукова література, комерційна документація тощо), призначені

25 Онуфрієнко Г. Продуктивний іменник термінологічної деривації. Вісник Національного університету «Львівська політехніка». Серія «Проблеми української термінології». 2004. № 503. С. 72.

26 Загородній А., Вознюк Г. Фінансово-економічний словник. Третє видання, доповнене та перероблене. Львів : Видавництво Львівської політехніки, 2011. 844 с. ; Економічний словник: банківська справа, фондовий ринок : українськоанглійсько-російський тлумачний словник / Л. Алексеєнко та ін. Київ : Максимум, 2000.529 c. 
широкому колу читачів, i описують терміни, що безпосередньо стосуються економіки та фінансів. Вони спеціалізовані, містять відповідну термінологію й допомагають студентам, керівникам підприємств, менеджерам тощо.

Економічна наука - це велика галузь знань, яка торкається не тільки законів і понять економічної діяльності, але й низки суміжних галузей. Тому терміни іншомовного походження утворюють численні тематичні групи, серед яких виділяють такі:

1. Назви приватних і державних структур, які утворюють різні типи об'єднань: консалтинг (англ. consulting - консультування із широкого кола питань економічної діяльності). Із цим поняттям пов'язана діяльність консалтингових фірм і консалтингових компаній, що виконують послуги 3 дослідження й прогнозування ринків, розробку маркетингових програм. Консалтингові фірми можуть бути спеціалізовані за окремими профілями); конщерн (англ. concern «участь», «інтерес» - добровільне об'єднання підприємств, яке здійснює спільну діяльність).

2. Назви різних економічних програм i видів комерційної діяльності (купівля-продаж товарів, оренда, торгове посередництво тощо): aympaŭm (англ. outright - «звичайний», «прямий» - обмінна форвардна валютна операція, що включає премію або дисконт); aymmрейд (англ. outtrade - невдала через нерозуміння сторін торгова угода); аутплейсмент (англ. outplacement - частина програми підтримки звільнених співробітників - надання допомоги для пошуку нової роботи); аутсорсинг (англ. outsourcing - використання зовнішньої організації (постачальника) для обробки фінансових даних під час здійснення комерційних операцій; експорт послуг - аутсортинг ресурсів, аутсортинг процесів).

3. Назви осіб економічної діяльності (статус, професія, вид заняття): aymсайдер (англ. outsider - особа, що не постійно спекулює на біржі, біржовий спекулянт - непрофесіонал.); джобер (англ. jobber) спекулянт на фондовій біржі, професійний біржовик. Джобер не має права виконувати функції брокера; конмен (англ. соптап - шахрай, який не викликає довіри. Конмен зустрічається у всіх видах підприємництва).

4. Назви нових професій, що визначають становлення нової моделі економіки: менеджер (англ. manager - «управлінець»), niap-менеджер (англ. PR manager - фахівець зі зв'язків із громадськістю), рієлтор (англ. realtor - агент із нерухомості).

$\mathrm{y}$ сучасних умовах стрімкого науково-технічного прогресу спостерігається залучення наукових термінів у повсякденне мовлення. Найбільш уживані слова трапляються в газетних і журнальних статтях, 
і часто без будь-яких пояснень. Варто зауважити, що для задоволення потреб мови з'являється багато додаткових слів. У багатьох іншомовних економічних понять в українській мові $є$ еквіваленти: iмnорт (import - «ввезення»), інфляиія (inflation - «знецінення грошей»), ліміт (limit - «обмеження»), маркет (market - «ринок»), ексnорm (export - «вивезення»). Замість слова «провайдер» можна вживати, і на практиці використовується, «постачальник», замість «девелопер» - «забудовник». Складність у тому, що в англійській мові дуже продуктивні утворення на -or i $-e r$, які в українській мові вимагають не одного слова, а щонайменше двох (banker - не тільки «банкір», а й «банківська організація», «банк»; realtor - не тільки «агент 3 нерухомості», але й «агентство нерухомості»). Проте трапляються й випадки «усічення» термінів під час перекладу, наприклад, balance sheet - «баланс», foreign exchange market «валютний ринок», average adjuster - «диспашер». Терміни поширилися внаслідок уживання, насамперед журналістами, а також перекладачами, які з об'єктивних причин транслітерують або дослівно перекладають (калькують) поняття.

Під час перекладу документів і матеріалів із різних сучасних сфер діяльності необхідно вирішувати широкий спектр лінгвістичних завдань, пов'язаних із наявністю так званих неологізмів. Під цим терміном розуміють різні лексико-семантичні новації: слова, словосполучення, що позначають нові предмети, явища й інші реалії, створені за словотвірними моделями певної іноземної мови. Неологізми можуть цілком природно викликати у процесі перекладу деякі труднощі, пов'язані як з відсутністю терміна в рідній нам мові, так і зі своєрідністю можливостей словотворення мови-оригіналу. Необхідно, зокрема, обгрунтовано й доцільно трансформувати іншомовні лексико-семантичні одиниці у відповідний вокабуляр української мови, а також розумно адаптувати їх у контексті конкретної тематики.

Треба зауважити, що перш ніж іншомовне слово увійде в українську мову, воно зазнає певних змін у мові-реціпієнті, стаючи власне неологізмом. У кожній мові існують власні словотвірні традиції та моделі, за якими й формується більшість неологізмів. В англійській мові слід виділити деякі базові моделі.

1. Неологізми, сформовані на основі словотвірних суфіксів, префіксів, наприклад, суфіксів -tion, -ism для іменників; -ize для дієслів; префікса $d e$ - та інших.

Суфікс -ism продуктивний для утворень категорій у політології та економічній теорії, як-от: brandalism (розміщення на громадських та офісних будівлях зовнішньої реклами, яка зазвичай спотворює їхній 
зовнішній вигляд); enronism (процес великомасштабного руйнування, часто через причини внутрішнього характеру).

Значна кількість дієслів-неологізмів утворюються з використанням суфікса -ize. Наприклад, to calendirize (складати календарний графік заходів); to operationalize (реалізовувати); to productize (перетворювати на товар, наприклад, послуги); to dollarize (про країну переорієнтувати національну економіку на долар); to genericize (робити що-небудь поширеним або масовим товаром); to enronize (маскувати фінансові проблеми спритним шахрайством і неприкритою брехнею); to socialize (оприлюднювати що-небудь, наприклад, ідею, для виявлення ставлення до неї).

Найпоширенішим префіксом для утворення неологізмів $\epsilon d e$ Наприклад, to de-proliferate (швидко скорочуватися); decruitment (евф. звільнення); to de-conflict (урегулювати конфлікт); to de-risk (зменшувати ризик).

Серед інших словотвірних елементів - суфікс -tion: floridazation (збільшення частки населення пенсійного віку в будь-якому регіоні); суфікс -ance: exceedance (перевищення кількості); суфікс -less: fabless (про фірму - не мають власних виробничих потужностей для виробництва); префікс dis-: to disclude («не включати»); префікс re-: re-purposing (використання змісту видання у друкованій формі в електронній формі); reskilling («перепідготовка») тощо. Шляхом словоскладання в англійську мову увійшли такі слова, як know-how («технологія», «ноу-хау»); desk time (час, реально проведений службовцям між нарадами); face-time (час на особисте спілкування 3 керівництвом, підлеглими або клієнтами на противагу спілкуванню телефоном, електронною поштою тощо); just-in-time (система поставок «точно у строк»); downsizing або rightsizing (оптимізація структури управління шляхом скорочення управлінських ланок).

2. Неологізми, сформовані на основі словотвірних способів англійської мови, шляхом складання основ, слів; outsourcing (використання зовнішнього ресурсу, передача організацією, на підставі договору, певних видів або функцій виробничої підприємницької діяльності іншій компанії, що працює в потрібній галузі), copyrighting («авторське право»), globalization («глобалізація»), cybercrime («інтернет-злочин»).

3. Неологізми, отримані у процесі переосмислення, набуття наявними поняттям нового значення. Наприклад, empowerment (наділення повноваженнями рядових співробітників), to codify (систематизувати інформацію), skyscraper (вертикальна лінія або рекламне оголошення на вебсторінці), shadow (приховане (тіньове) ціноутворення), sheet (бухгалтерський баланс). 
4. Неологізми, утворені продуктивним в англійській мові способом абревіації, усічення. Наприклад, VAT (податок на додану вартість Value Added Tax).

5. Певна кількість неологізмів, здебільшого дієслів, утворюються шляхом конверсії, трансформації синтаксичної ролі слів. Наприклад, to patent (запатентувати), to version (створювати нову версію чогонебудь), to text (друкувати текст), to amazon (здійснювати покупки на сайті Amazon.com), to transfer (здійснювати банківський переказ), start-up (запускати, «стартап-компанія» - нещодавно створена інноваційна організація, часто інтернет-компанія, проєкт).

6. Нерідко трапляються неологізми, які є евфемізмами - словами, що замінюють певні слова або вирази на більш доречні. Наприклад, career-change opportunity (замість «звільнення»), opposition research (замінює «пошук компромату»).

Досліджуваний матеріал уможливив розрізнення англіцизмів за ступенем новизни:

1) абсолютні неологізми: авераж (англ. average - «біржова операція»), брейк-івен (англ. break-even- «точка беззбитковості»), аваль (англ. aval - порука за векселем);

2) слова з відносною новизною, затребувані суспільством у зв'язку 3 комунікативною актуальністю: приватизація (англ. privatization процес передачі державної власності у приватні руки); рієлтер (англ. realtor - фахівець у галузі нерухомості), сnонсор (англ. sponsor), офшор (англ. offshore), сток (англ. stock - «запас», «зберігати на складі»), кешбек (англ. cash-back - «відстрочена знижка»), сейл (англ. sale - «розпродаж»), шопінг (англ. shopping - «похід по магазинах»), дисконт (англ. discount - «знижка»);

3) неологізми, які характеризують реалії сучасного життя: бізнес (англ. business), демпінг (англ. duтping), брокер (англ. broker), кліринг (англ. clearing).

Складнощі перекладу й розуміння неологізмів пов'язані зі стрімким розвитком науки й техніки в сучасному світі. На жаль, словники не встигають оновлюватися настільки ж стрімко, як з'являються нові слова в мові різних галузей знань. Неологізми - це нормальне явище в будь-якій мові, тому відсутність слова у словнику не повинна бути перешкодою під час перекладу. Перекладацька практика є джерелом збагачення лексичного складу мови. Неологізми перекладаються українською у два етапи:

- уточнення значення неологізму шляхом звернення до свіжих видань англійських тлумачних словників 3 урахуванням контексту й структури слова; 
- здійснення перекладу з допомогою таких засобів української мови, як транскрипція, транслітерація, калькування, описовий переклад. Вибір способу перекладу неологізму залежить від низки таких суб’єктивних чинників, як досвід перекладача, стиль тексту тощо.

\section{2. Функції англізмів, зреалізовані в українському економічному дискурсі (на матеріалі засобів масової інформаціїі)}

Англомовні запозичення в українській економічній пресі виконують різні функції. Незаперечним фактом $є$ те, що мова вимагає введення нової лексичної одиниці за необхідності використання нового поняття, яке не має власного позначення в українській мові (factoring факторні операціï, futures - ф'ючерси). У такій ситуації запозичення виконують номінативну функцію, наприклад: «На Украӥнській біржі відкрита торгівля ф'ючерсними контрактами на зернові культури. Особливість поставного ф’ючерсу в тому, що під час виконання контракту передбачається постачання зерна покупию, водночас відбувається реальна зміна власника аграрної продукції» (Finance.ua, 10 серпня 2017 р.). «Сьогодні практично всі великі колекторські компанії пропонують своїм клієнтам кілька варіантів співпраці у сфері роботи із простроченими заборгованостями, - розповідає експерт колекторського агентства Verdict. - Основні з них ие - факторинг, або викуп проблемних боргів, $i$ робота за агентською комісією» («ВКурсе», 29 липня 2010 р.). Англомовне запозичення factoring передає спеціальне значення «факторні операції» для орієнтації фахівця 3 економіки у професійному просторі, водночас варто зазначити, що така функція запозичень, беручи участь у процесі пізнання економістами свого професійного простору, безпосередньо пов'язана 3 пізнавальною функцією мови.

Стрімкі зміни в економічній картині світу сприяють виникненню нових понять, явищ або ідей, водночас запозичені в українську чи інші європейські мови англіцизми дозволяють заповнити утворені лексичні лакуни й збагатити професійну мову економістів одиницями точної семантичної диференціації, наприклад: «Сьогодні, 26 травня, депутати Львівської міськради затвердили договір про реалізацію партнерського проекту «Вулиия для всіх - партисипативне планування вулиці у Львові». На ией проект передбачено витратити 80 тисяч євро, з яких 1 тисячу - на друк фласрів» (ZIK, 26 травня 2016 р.). У Росії з купюр у сто рублів вирішили зробити фласри до Чемпіонату світу з футболу, що пройде у РФ з 14 червня по 15 липня 2018 р.» («Інформаційний акцент», 25 липня 2018 р.).

Англомовні запозичення в українській економічній пресі здатні виконувати розпізнавальну (ідентифікаційну) функцію, вказуючи на 
певну приналежність комунікантів до професійної сфери економіки. Наприклад: «На ринку Форекс є відомі трейдери, які майже завжди отримують прибуток, $i$ їх поточний стан обчислюється мільярдами. За даними різних аналітиків, кількість трейдерів, які мають невеликий дохід, або навпаки, невеликий збиток, приблизно однакова» («Погляд», 24 січня 2018 р.). "Міжнародний енерготрейдер з реєстрацією у Швейцарії, компанія DufEnergy, уперше поставив природний газ на адресу своєї дочірньої української компанії "Дюфенерджі Україна»» (Finance.ua, 1 лютого 2018 р.).

Використання запозичень надає висловлюванню спеціального забарвлення професійної приналежності, і часто така лексика зрозуміла лише вузькому колу фахівців цієї сфери. Мова преси передусім орієнтована на масову передачу інформації, i це визначає умови певного комунікативно-прагматичного простору. Використання англіцизмів у сфері економіки дозволяє подати інформацію у зручній для адресата формі, зробити висловлювання придатнішим для позначення низки виробничих процесів і передати інформацію в межах професійної групи. У такому разі можна говорити про їхню комунікативну функцію: «У столиці розпочався тиждень ділової доброчесності, щзо об'єднав бізнесменів, які прагнуть вести діяльність чесно та прозоро. Участь у периому дні тижня ділової доброчесності взяли керівник та портфоліо-менеджер напряму Демократичне врядування ПРООН в Украӥні Маркус Бранд, директор СБРР в Україні Шевкі Аджунер, повідомляє кореспондент Укрінформу» (Укрінформ, 20 липня 2018 р.). Як показують ці приклади, уживання запозиченої лексики дозволяє виконати функцію інформування адресата, водночас лексема може бути незнайомою неспеціалістам цієї сфери.

Належність до певної професійній сфери передбачає визначений рівень компетентності, а також включає в себе знання професійної лексики. Економічна преса частково обмежує цільову аудиторію, але прагне встановити тісний контакт зі своїм безпосереднім адресатом. У такій ситуації актуалізується контактовстановлювальна функція англомовних запозичень в українську мову. Англомовні терміни в тексті привертають увагу фахівців, це якимось чином зближує їх $\mathrm{i}$ сприяє встановленню більш тісного контакту. Водночас варто зауважити, що у професійному середовищі часто використовується спеціалізована лексика (професіоналізми, жаргонізми), яка приховує інформацію від людей, не обізнаних із реаліями цієї професійної діяльності, i дозволяє вступати в комунікацію, залишаючись незрозумілою.

Використання запозичень замість відповідних українських термінів здатне зробити мову в економічному дискурсі більш образною й емоційною, виконує функцію експресивності: «Без урахування групи 
«Приват» у нас частка "bad debts" (погані борги) ТОП-5 бізнес-груп uе 82\%. 3 «Приватом»- ие 93\%» («Економічна правда», 23 червня 2018 р.). «У 2012 р. європейські компанії списали 350 млрд євро у вигляді “bad debts”, щзо стало рекордним значенням, яке перевищує річні ВВП Австрії, Данії або Фінляндіï» (Кореспондент.net, 13 травня 2013 р.). Такі приклади англомовного запозичення в економічному дискурсі показують іронічну оцінку описуваного явища.

Більшість розвинутих мов мають власну економічну термінологію, проте фахівці вважають за краще використовувати англомовні аналоги деяких понять, оскільки часто вони точніше висловлюють критичне ставлення до денотата. Використання в українській економічній пресі англіцизмів 3 евфемістичною функцією безпосередньо корелює 3 функцією експресивності, оскільки завдання евфемії - уникнути соціальних, міжособистісних конфліктів, комунікативної напруженості й некоректності. Евфемістична функція англіцизмів пов'язана із процесами, що відбуваються в соціумі. Евфемія має зв'язок з табу, будучи не тільки когнітивно-дискурсивним, але й соціокультурним феноменом, що демонструє зміни в цінностях різних культур. В економічному дискурсі ця функція регулярно реалізується у статтях, які стосуються малозабезпечених або занадто економних представників населення: «»Міжнародні авіалінії України» ввели новий тариф low-cost з додатковими обмеженнями $і$ одночасно значно знизили ціни на авіаквитки на внутрішні $i$ міжнародні рейси» («Економічна правда», 12 травня 2017 р.). Використання англіцизмів дозволяє подати явище в більш увічливій і коректній формі порівняно з українським еквівалентом. В європейських мовах, наприклад, для позначення осіб, яким за п'ятдесят, маркетологи й рекламісти використовують англомовні евфемізми: Die Generation der "Best Agers", Die Generation "Silver", “Golden Customer". Це пов'язують із тим, що в Європі представники цієї вікової групи часто найбільш купівельноспроможні.

Запозичені англіцизми дозволяють виконувати функцію економії мовних засобів і з мінімальними мовними витратами досягти необхідного ефекту. Яскравим прикладом служать запозичення-акроніми й абревіатури, які здатні передавати точне семантичне позначення: «Якщо акиіонери чогось не розуміють, вони йдуть, умовно кажучи, на курси й вчаться, ще таке $P \& L$, cash flow тощо. Вони розбираються, як влаштований ринок, які технології існують, як подібні компанії борються зі свойми проблемами, які взагалі $\epsilon$ бізнес-рішення $i$ практики» («Українська правда», 23 лютого 2016 р.). Такі запозичення, з одного боку, сприяють економії мовних засобів (замість українського словосполучення використовується одне слово англійською), але, з іншого боку, частіше вимагають пояснень для адресата, оскільки можуть бути неправильно 
витлумачені або не зрозумілі. Цей факт також зумовлює великий ступінь їх використання в писемному мовленні.

Уживання англомовного запозичення дозволяє звузити значення лексичної одиниці, прив'язавши її до конкретного явища. У такому разі йдеться про виконання функції конкретизації значення для більш точного позначення явищ. Треба зазначити, що деякі англомовні запозичення в українській пресі здатні миттєво виконувати кілька функцій і можуть не тільки висловлювати професійну приналежність, але також нести в собі експресивність, сприяти мовній економії та смисловий точності. Усебічний аналіз характерних властивостей англомовного економічного дискурсу й пошук способів гармонізації ділового спілкування $є$ надзвичайно важливим завданням гуманітарних досліджень. Велику увагу привертають до себе способи підвищення комунікативної ефективності економічного дискурсу, зокрема шляхом поповнення словникового складу професійним жаргоном ${ }^{27}$.

Лексичні та фразеологічні англомовні запозичення являють собою основний інструмент розширення термінологічного фонду мови. 3 огляду на динаміку процесів, що відбуваються в суспільстві, поповнення лексико-фразеологічного фонду може розглядатися як еволюційна закономірність і мовна максима. Орієнтація представників великої частини європейських співтовариств на пріоритетне оперування англомовними професійними запозиченнями може сьогодні розглядатися як ключова специфіка сучасної мовної ситуації.

Отже, лексика запозичується для того, щоб дати назви новим об'єктам і поняттям, для яких немає назв у лексичному складі цих мов. Проте запозичення з культур-домінантів нерідко виявляються пов'язані 3 об'єктами й поняттями, які не асоціюються 3 культурними нововведеннями: причиною запозичення може стати «статус» нового слова, його «престижність».

Запозичення можуть мати двосторонній характер (коли дві мовні спільноти запозичують одна в одної), проте «частки» запозичень у таких випадках виявляються нерівними. Односторонні запозичення, 3 іншого боку, нерозривно пов'язані 3 поняттям культурного домінування, наслідком якого стає культурна дифузія. Так, наприклад, протягом XX ст. основним джерелом поповнення словникового запасу для більшості мов була англійська. Запозичення 3 американської культури здебільшого також є односторонніми.

Під час вивчення процесу запозичування професійної лексики 3 однієї мови в іншу зазвичай у дослідника виникають такі питання: як i чому відбувається запозичення з інших мов; з яких мов і в які вони

27 Malyuga E., Tomalin B. English Professional Jargon in Economic Discourse. Journal of Language and Literature. 2014. Vol. 5. № 4. 
запозичуються; як запозичення входять до системи інших мов. Процес адаптації починається тільки-но англійське слово потрапляє в іншу мову. Запозичений лексичний елемент насамперед адаптується на фонологічному рівні. На цьому рівні англійські фонеми замінюються на фонеми, властиві мові-реципієнту. Чотири можливі сценарії цього процесу прогнозує Р. Філіпович ${ }^{28}$ :

1) адаптація відповідно до вимови запозиченого слова;

2) інтеграція слова у фонологічну систему мови-реципієнта;

3) адаптація відповідно до написання й вимови як двох взаємопов'язаних чинників;

4) адаптація відповідно до проміжних змін, внесеними мовоюпосередником (у випадках, коли запозичене слово вже $є$ запозиченим в англійській мові).

Досліджуючи запозичення з англійської мови, необхідно пам'ятати, що англійський лексикон сам містить велику кількість запозичених слів, а отже, деякі слова запозичуються безпосередньо, тоді як певна частина нових слів переходять у мову в уже зміненій формі. Найчастіше це стосується міжнародних термінів і слів, наявних у багатьох мовах. Такі слова повністю інтегровані в систему англійської мови й функціонують у ній як питомі англійські лексичні одиниці.

\section{ВИСНОВКИ}

Особливе місце на сучасному етапі розвитку суспільства належить англіцизмам в галузі економіки, що зумовлено розвитком соціальноекономічних зв'язків і міжкультурної комунікації у світовому масштабі. Глобальні процеси модернізації науково-технічної бази також сприяють інтенсифікації взаємодії та взаємовпливу мов, неологізації лексичного складу. У сучасній українській мові функціонують слова на позначення нових реалій, частотність уживання яких перевершує частотність уживання питомих відповідників; значна кількість англіцизмів $є$ незамінною. Під час адаптації іншомовні слова піддаються змінам, підпорядковуючись законам розвитку українській мови, і ці процеси потребують подальших наукових досліджень.

Проведений аналіз англомовних запозичень як невід'ємного компонента професійної мови дозволив виділити їхні найважливіші функції в економічному дискурсі української мови. Виявлено такі функції англомовних запозичень, як: номінативна, розпізнавальна, комунікативна, контактовстановлювальна, функція мовної економії, конкретизації значення й експресивності, що включає в себе евфемістичну функцію. Динаміка суспільних процесів і пов'язане 3

28 Filipovic Rudolf. Semantic Changes in Adaptation of English Loanwords in Serbo-Croatian. Studia Romanica et Anglica Zagrebiensia. № № 25-26. Zagreb,1968. 
ними поповнення лексико-фразеологічного складу мови змушує представників українських професійних співтовариств орієнтуватися на пріоритетне використання англомовних фахових запозичень. Дослідження показало, що, маючи досить обмежену сферу поширення, у певній комунікативній ситуації запозичення здатні виконувати одночасно кілька функцій, дозволяючи заповнити лексичні лакуни та збагатити професійну мову економістів лексичними одиницями точної семантичної диференціації. Здійснений аналіз не охоплює всі аспекти проблеми лексичних запозичень в економічному дискурсі, проте визначає перспективу цього мовознавчого напряму.

\section{АНОТАЦІЯ}

Поряд із розширенням сфер використання спеціальної іншомовної термінології в галузях економіки, фінансів, комерційної діяльності тощо спостерігається поява запозичень-неологізмів. I ці процеси, звичайно ж, вимагають аналізу й узагальнення. 3 огляду на суспільну актуальність явищ запозичування й неологізації все більшого значення набуває вивчення особливостей англіцизмів в україномовній економічній комунікації. У роботі подано характеристику своєрідності процесу інтеграції новітніх англіцизмів (способи творення, особливості перекладу й засвоєння) в українську термінологію економічної галузі. Здійснено аналіз англомовних запозичень, регулярно вживаних у засобах масової інформації, визначено основні функції (номінативна, розпізнавальна, комунікативна, функція мовної економії, конкретизації значення й експресивності), які можуть одночасно зреалізовуватися ними в українському економічному дискурсі, дозволяючи заповнити лексичні лакуни й збагатити професійну мову економістів новими лексичними одиницями.

\section{ЛІТЕРАТУРА}

1. Ажнюк Б. Мовні зміни на тлі деколонізації та глобалізації. Мовознавство. 2001. № 3. С. 48-54.

2. Ажнюк Б. Слов'янські й неслов'янські запозичення в мові української діаспори. Мовознавство. 1998. № 2. С. 145-160.

3. Економічний словник: банківська справа, фондовий ринок : українсько-англійсько-російський тлумачний словник / Л. Алексеєнко та ін. Київ : Максимум, 2000. 529 с.

4. Архипенко Л. Особливості адаптації запозичень із німецької мови в систему української економічної термінології. Одеський лінгвістичний вісник. Спецвипуск, 2017. С. 26-29.

5. Ахманова О. Словарь лингвистических терминов. Москва : Советская энциклопедия, 1966. 606 с. 
6. Ефремов Л. Сущность лексического заимствования и основные признаки освоения заимствованных слов : автореф. дис. ... канд. филол. наук. Алма-Ата : Казахск. ун-т, 1959. 21 с.

7. Загородній А., Вознюк Г. Фінансово-економічний словник. Третє видання, доповнене та перероблене. Львів : Видавництво Львівської політехніки, 2011. 844 с.

8. Ковальчук О., Романчук Д. Розвиток іншомовних запозичень в українській економічній лексиці. Наукові записки Національного університету «Острозька академія». Серія «Філологія». 2013. Вип. 37. C. $149-151$.

9. Костомаров В. Языковой вкус эпохи. Москва, 1994. 218 с.

10. Крысин Л. К определению терминов «заимствование» и «заимствованное слово». Развитие лексики современного русского языка. Москва : Наука, 1965. С. 104-116.

11. Лисенко О. Освоєння німецькомовних запозичень в українській науково-технічній термінології : дис. ... канд. філол. наук. Харків, 1999. $179 \mathrm{c}$.

12. Майоров М. К вопросу о сущности лексического заимствования. Ученые записки 1-го Московского государственного института иностранных языков им. М. Тореза, 1967. Т. 37. С. 196-235.

13. Мрозіцька У. Інтра- та екстралінгвістичні чинники розвитку мови-реципієнта (на матеріалі латинських запозичень в українській мові) : автореф. дис. ... канд. філол. наук. Київ, 2002. 18 с.

14. Навальна М. Динаміка лексикону української періодики початку XXI ст. Київ : Інститут української мови ; Видавничий дім Дмитра Бураго, 2011.328 c.

15. Огиенко И. Иноземные элементы в русском языке : История проникновения заимствованных слов в русский язык. Киев : Тип. Бондаренко и Гнездовского, 1915. 136 с.

16. Олійник А. Роль запозичень-англіцизмів у розвитку сучасної української мікроекономічної термінології : автореф. дис. ... канд. філол. наук. Київ, 2002. 20 с.

17. Онуфрієнко Г. Продуктивний іменник термінологічної деривації. Вісник Національного університету «Львівська політехніка». Серія «Проблеми української термінологї̈». 2004. № 503. С. 71-74.

18. Пілецький В. Мовна самобутність терміна. Українська термінологія і сучасність : збірник наукових праць. 2009. Вип. VIII. C. $49-54$.

19. Розенталь Д., Теленкова М. Словарь-справочник лингвистических терминов. Москва : Наука, 1976. 543 с.

20. Сергєєва Г. Англомовні запозичення в українській правничій термінології : автореф. дис. ... канд. філол. наук. Харків : Харківськ. держ. ун-т, 2002. 16 с. 
21. Симонок В. Лексико-семантична рецепція іншомовної лексики в українській мовній картині світу : автореф. дис. ... докт. філол. наук. Харків : 2002. 36 с.

22. Сорокин Ю. Развитие словарного состава русского литературного языка в 30-90-е годы XIX века. Москва ; Ленинград : Наука, 1965. 159 с.

23. Стецюк С. Англомовні запозичення в українській фінансово-економічній термінології. Проблеми української термінології : збірник наукових праць учасників XII Міжнародної наукової конференції «Проблеми української термінології СловоСвіт 2012», Львів, 27-29 вересня 2012 р. Львів : Видавництво Львівської політехніки, 2012. С. 52-54

24. Стишов О. Українська лексика кінця XX століття (на матеріалі мови засобів масової інформації). Київ : Вид. центр КНЛУ, 2003. 288 с.

25. Українська мова : енциклопедія. Київ : Вид-во «Українська енциклопедія» ім. М.П. Бажана, 2004. 820 с.

26. Федорець С. Англійські запозичення в мові сучасної української реклами : автореф. дис. ... канд. філол. наук. Харків, 2005. 20 с.

27. Хауген Э. Лингвистика и языковое планирование. Новое 6 лингвистике. Вып. 6. Москва : Прогресс, 1975. С. 344-382.

28. Чуєшкова О. Аналітичні номінації в економічній терміносистемі (структурно-типологічний аспект) : дис. ... канд. філол. наук. Харків, 2002. $189 \mathrm{c}$.

29. Filipovic Rudolf. Semantic Changes in Adaptation of English Loanwords in Serbo-Croatian. Studia Romanica et Anglica Zagrebiensia. № № 25-26. Zagreb, 1968.

30. Malyuga E., Tomalin B. English Professional Jargon in Economic Discourse. Journal of Language and Literature. 2014. Vol. 5. № 4.

\section{Information about the authors:} Arkhypenko L. M., Candidate of Philological Sciences, Associate Professor at the Department of Ukrainian Studies and

Language Preparation of Foreign Citizens Kharkiv National University of Economics named after Semen Kuznets 9a, Nauky ave., Kharkiv, 61000, Ukraine

Melnyk P. V., Master's Degree in Philology, Member of Ukrainian Parliament, Chairman of the Subcommittee on Coordination of European Union Technical Assistance Programs and Cooperation with Euratom of the Parliament Committee of Ukraine's Integration into the European Union 5, Grushevskogo str., Kyiv, 01008, Ukraine 